\title{
The Socio-Political Impact of Trauma as Experienced by the African National Congress's Political Activists in the Free State Province, 1970-1994
}

\author{
Khotso Pudumo \\ Chitja Twala \\ Buti Kompi \\ Faculty of the Humanities, Departments of History, \\ University of the Free State, Bloemfontein, South Africa \\ E-mail: twalacm@ufs.ac.za
}

Doi:10.5901/mjss.2014.v5n3p568

\begin{abstract}
During the apartheid era in South Africa, there were significant activities and events taking place within and outside the country in as far as the liberation struggle was concerned. The banning of the liberation movements in 1960 and the subsequent launch of an armed struggle led to dramatic change in the lives of millions of South Africans. Participants in the sabotage campaign and other underground activities, exile, military training and action, imprisonment, death in detention, banishment, torture, imprisonments without trial, house arrests, constant surveillance and harassment, and general involvement in the struggle against apartheid characterised the psychological and physical traumatic experiences of the political activists in the Free State Province. The traumatic experiences of the political activists in the Free State forms part of the tapestry of South Africa's liberation history. The article gives a reflection of the political activists' memory against the state of forgetting.
\end{abstract}

Keywords: Liberation Movements, Liberation Struggle, Exile, Liberation History, Human Rights

\section{Introduction}

The main purpose of this study is to provide a chronological and thematic analysis into the traumatic experiences of the political activists in the province during the apartheid era. The subtle and later vibrant political activism in the province led to acts of brutality. The study was necessitated by the following reasons: Firstly, the dearth and lacuna in literature in as far as the recording the traumatic experiences of the political activities in the Free State was concerned. Secondly, the human rights abuses are documented by academics and other interested parties, and little from oral testimonies have been subject for further academic scrutiny.As mentioned previously, the article tries to create an awareness of human rights abuse as part of the struggle of memory against forgetting. Using the oral testimonies, the article highlights the activities of some of the courageous individuals who were either psychologically or physically traumatised for refusing to submit to racial oppression and apartheid tyranny.

The study departs from the premise that although in South Africa there were platforms and sessions such as the Truth and Reconciliation Commission (TRC) whereby the political activists shared their traumatic experiences, a lot was not disclosed in such sessions. Perhaps this was due to the fact that some political activists were not part and parcel of the TRC process. Sometimes, those who went to the TRC failed to divulge the whole information relating to their traumatic experiences. Therefore, due to the above, it became clear that 'truth telling' was to a certain extent compromised.

The study attempts to answer the following questions: How were the political activists identified by the agents of the ruling National Party's (NP's) government? After being arrested, how were they exposed to measures of physical and psychological torture? How these political activists dealt with such traumatic experiences prior and post democratic era? Did these political activists receive therapy or not?

\section{Aims and Objectives of the Study}

The initiation of this study was encouraged by the proceedings of the TRC in South Africa when the authors listened with 
loathing to the apartheid foot soldiers as they narrated their acts of torture and murder and pleaded not to be persecuted for the crimes. In the same vein, the authors were concerned with the cries of the victims and family members of those who were killed by such murderers when the confronted them and asked what the last words of their loved ones had been before they died.

Almost two decades after democracy has come to South Africa, it is probably worth examining closely what the assumptions of such trauma were. The authors are appreciative of the fact that the experiences of torture or abuse are an extraordinary life experience capable of causing in any person a wide range of physical and psychological suffering and disability. The article acknowledges the fact that trauma was not only experienced by those political activists who were directly or indirectly involved in political activities, but also their immediate family members and distant relatives. By telling their stories, these political activists contribute to the agenda of celebrating the roles played by the heroes and heroines who sacrificed their lives for the liberation of South Africa from the shackles of apartheid.

\section{Literature Review}

Most recently, academic studies were undertaken by historians, sociologists and political scientists such as Twala (2010), Seekings (2010) and Moloi (2012) on the political history of the Free State, but little documented about the traumatic experiences of the political activists. These studies became handy for the purpose of this article. Despite the attempts by the afore-mentioned academics, no in-depth analysis of the traumatic experiences of the Free State political activists has been pursued. Furthermore, the studies on the TRC also never concentrated much on the traumatic experiences of the political activists (Oelofse, 2007; Mbatha, 2011).

For the purpose of this study, sources on trauma and how it leads to post-traumatic stress disorder were used. In most cases, the authors of this literature wrote from psychology as a discipline (Prager 2011: p425-448; Kagee 2005: p623; Kagee 2006: p11; Halvorsen and Kagee 2012: p 990). Using literature from psychology as a field of study and interrogating it to give evidence to history, the researchers hopes to make a contribution to the understanding of the trauma as experienced by the political activists in the Free State during the apartheid era.

\section{Theoretical Framework}

This section analyses the different physical and psychological theories related to posttraumatic stress disorder. Brewin and Holmes (2003: p339-376) suggested few theories, namely, dual representation theory indicates 'that trauma victims, whose attention tends to be captured by the immediate source of threat and who may report that they simply failed to hear words that were shouted or shots that were fired in close proximity to them'. Dual representation theory attempts to include observations made by both social-cognitive and information processing perspectives within an overarching framework that explicitly differentiates cognitive process happening during the trauma from the more extensive appraisals that occur afterwards (Brewin and Holmes, 2003: p361).

Horowitz (1976) argues that when faced with trauma, people's initial response is outcry at the realisation of the trauma. A second response is to try to assimilate the new trauma information with prior knowledge. At this point, many individuals experience a period of information overload during which they are unable to match their thoughts and memories of the trauma with the way that they represented meaning before trauma. In response to this tension, psychological defense mechanisms are brought into play to avoid memories of the trauma and pace the extent to which it is recalled. For example, the individual may be in denial about the trauma, feel numb, or avoid reminders of it. The above theories became evident in the traumatic experiences by the ANC's political activists during the period under discussion.

\section{Research Methodology}

The study provides new insight into the challenges experienced by the political activists in the Free State Province. More importantly, it includes the voices of scores of political activists whose courageous and selfless battle against the apartheid regime in the 1970 s until the early 1990s exacted high price, in the form of human rights abuses. Therefore, as previously mentioned, the article relies on oral testimonies as told by those political activists and their contemporaries. Furthermore, a narrative approach is pursued whereby their memories are recorded, in some instances, before they were forever silenced by death. The information collected via conducting interviews was supported by comprehensive literature surveys incorporating chapters in books, books, journal articles, dissertations, reports, newspaper articles and to a certain extent electronic sources. 
The study follows a qualitative approach by including an interpretation of observations for the purpose of discovering and understanding meanings and patterns underlying both the physical and psychological trauma as experienced by the political activists. The aim is to provide an in-depth understanding in order to determine the impact of the role played by the repressive National Party's (NP's) government in this regard. To a certain extent, the inferences are drawn deductively from the historical context of the political situation within South Africa during the 1970s and the early 1990s.

\section{Findings and Discussion}

\subsection{Trauma in historical context}

Different authors define the concept trauma differently. Although, the main definitions of trauma are related to psychology as a discipline, in this study an attempt is made to try and conceptualise it in historical context. This is done by firstly unpacking the concept traumatic history. It is important to note that by framing the experiences of the ANC's political activists at the hands of the apartheid state in terms of a trauma discourse, the assumption was that such individuals required psychological treatment to restore psychological health and well-being. Among former political activists, who had presumably been willing to make personal sacrifices for communal and political purposes in the form of political activism, with its accompanying risks of imprisonment, physical danger and possible death, a communal construction of psychological distress was more likely.

\subsection{The meaning of trauma}

The meaning adopted in the explanation of this study is derived from psychology as a discipline. Often trauma is used to refer both to negative events that produce distress and to the distress itself. In most cases, the definition of trauma does not name types of trauma or traumatic events. Instead it describes the experience of trauma and highlights the factors that influence the perception of trauma. Technically, trauma refers only to the event, not the reaction, and should be reserved for major events that are psychologically overwhelming for an individual. The Diagnostic and Statistical Manual of Mental Disorders (Anon, 2000: p463) defines trauma as follows: 'Direct personal experience of an event that involves actual or threatening death or serious injury, or other threat to one's physical integrity; or witnessing an event that involves death, injury, or a threat to the physical integrity of another person; or learning about unexpected or violent death, serious harm, or threat of death or injury experienced by a family member or other close associate. The person's response to the event must involve intense fear, helplessness, or horror'. While we acknowledge the above definition, one criticism pertains to the requirement that limits trauma to 'threatened death or serious injury, or other threat to one's physical integrity'. This is deemed unjustifiable since many events may be traumatic even if life threatening or injury is not an issue. Therefore, this article on the traumatic experiences of the political activists will share some light on that.

Psychological trauma is the unique individual experience of an event or enduring conditions in which the individual's ability to integrate his/her emotional experience is overwhelmed or the individual experiences (subjectively) a threat to life, bodily integrity or sanity (Giller, s.a). The authors of this article contend that, in the context of this study, trauma took place in environments whereby it was normative for it to occur. Wilson and Raphael (1993: p2) confirmed the following about a traumatised person:

A traumatised person is the one who experience an event that was outside the range of usual human experience that would be markedly distressing such as the sudden destruction of one's home or community and witnessing another person who has been seriously injured, killed as a result of an accident or physical violence.

\subsection{Major traumatic events as experienced by the by the political activists}

\subsubsection{Rape and sexual assault:}

Rape is not just unwanted sex, it is a highly traumatic experience and like other traumas it has negative effects on those who survive it. It is usually experienced as life threatening and as an extreme violation to a person (Koss, 1993: p198222). Political activists who experienced this form of trauma, their physical self were violated and in cases where the female activists who were raped as a way to silence them and to curb their political activism. Rape was mainly used to instil fear in them, that they should not be involved in the struggle for liberation. 


\subsubsection{Trials and imprisonment:}

Solani and Nieftagodien (2004: p392) argues that: 'Imprisonment allowed the state to monitor closely those it offended most and place them at the mercy of apartheid's authorities. Warders enforced prison procedures slavishly and, at least in some cases, callously. The South African penal system allowed for distributing individuals, fixing them in space, classifying them, extracting from them the maximum in time and force, training their bodies, coding their continuous behaviour, maintaining them in perfect visibility, forming around them an apparatus of observation, registration and recording, constituting from them a body of knowledge that is accumulated and centralised'.

Throughout the 1970s and 1980s, the state prosecuted activists from almost all layers of political opposition. With the leaders of the ANC behind bars, trials against rank and file members of the organisation continued as the state agents systematically mopped up residual pockets of resistance. Even the mere contemplation of sabotage could result in long terms of imprisonment. The account by ex-prisoners of their journeys from various places of detention to Robben Island bear testimony to the dehumanisation they experienced. Equally, the boat trip from Cape Town harbour to Robben Island was no less traumatic than the long journey that preceded it. The majority of prisoners had never been on a boat before, let alone on the rough seas around Cape of Storms. The physical trauma of the boat trip was matched only by the emotional pain of prisoners embarking on the final leg of their journey to long-term incarceration (Solani and Nieftagodien, 2004: p392-393).

Every aspect of prisoners' lives was regulated. In order to inflict trauma on the political activists, the monotonous regimen of sleep, eat, and work was strictly enforced and monitored. As argued by Solani and Nieftagodien (2004: p397) 'in most cases, prisoners were constantly reminded that they had no rights, and that even the most basic privileges were subject to the whim of the authorities. Visits from and correspondence with family members were denied at any time, and without any reasons being given. Both limitations on contact with those outside and isolation from fellow inmates were used as punishment. Study privileges and access to newspapers were withheld and the numbers of letters or visits were curtailed according to which group prisoners were categorised into'.

Sometimes the political activists were traumatised by being placed in solitary confinements. This meant that a political activist would be placed in a single cell for a week or two. However, Mbatha (2011: p15) contends that solitary confinement was aimed at manipulating the detainees' psyche, since they were locked up individually in probably dark cells for weeks or months. The authorities knew that was traumatic to the majority of the detainees and could torment them mentally. N Choane (2012) recalls:

You would be kept alone in solitary confinement for an extended period of time without knowing what they were busy investigating because on the interrogations one would tell them everything. One would be placed there and in the meantime trying to get incriminating information from you or even evidence. If they don't succeed in that, one would be kept there in the cells indefinitely. You will be alone in the cell for two weeks or more. The only thing you would be given was the Bible and that crushed you as a person.

In prisons, poisoning was increasingly favoured as a method of torture during the better part of the 1980s. D Coetzee who was based with the Special Branch (SB) in Bloemfontein in the early 1980s told the TRC that a senior SB member, described by him as 'one of the meaner security police stalwarts', discussed with him the use of poison as a means of 'disposing of activists'. For example, poison was used in torture of SM Maile in a Bloemfontein police cell where he was held in 1983. He was allegedly forced to drink poisoned liquor and was rushed to Pelonomi hospital where he died the same day (TRC Report, p351-352).

\subsubsection{Threats of death}

Death in prisons and detention was a concern for all political prisoners as well as their families. There were many stories in some parts of the country whereby political activists were abducted and later killed by members of the Askari. Not only the members of the Askari were notorious for these killings, but also the SBs. O Khoabane (2012), a political activist in Thabong Township during the 1980s remembers:

For me the brutality of the apartheid aligned structures such as the Askaris was felt when Zuka Baloyi was killed in Gugulethu, Cape Town. It was so unfortunate that Zuka Baloyi was killed in Cape Town while most of us had thought that he had done to exile. I think he had infiltrated the country to do some operational work of the ANC when he was killed. The assassination of Zuka Baloyi traumatised most of us who were closer to him. It was clear to us that somebody had sold him out. 
Another student activist in Thabong, Billyboy Mokobo was traumatised when in 1985 a petrol bomb was thrown at his parents' house. He sustained injuries. Realising that his life was in danger, after that incident Mokobo left the country for exile. Mokobo's elder brother C Mokobo (2012) noted:

In the mid-1980s, Thabong Township was volatile. There were youth and student organisations in the township. My brother who was a member of COSAS was regarded as a ring leader. Therefore, the police made attempts to eliminate him. This started long before our house could be petrol-bombed... At one stage the police tried to set him up by sending a girl to befriend him. Later in 1985 they threw a petrol bomb to our house. That was when we realised that we were in danger. Billyboy was the first to escape and skip the country. I followed him later. The whole family was under constant surveillance by the police. To us the only option was to go to exile.

In his article The Dynamics of Posttraumatic Stress Disorder in South African Political Ex-Detainees, $\mathrm{K}$ Solomons stated 'in almost all cases, ex-detainees reported feeling and thinking that the traumatic stressor was going to kill or severely and permanently damage and maim them. This sense of impending death was experienced at some point during the traumatic episode and not necessarily during the peak of pain' (1989: p209).

\subsubsection{Clashes with the vigilante and gangster groupings}

In some instances the ANC aligned activists were traumatised by the vigilante and gangster groupings established in the different townships of the province. ANC activists under the umbrella of the United Democratic Front (UDF) launched attacks to the councillors which were regarded as apartheid creation. They demanded the councillors to resign. Orange/Vaal industrial triangle townships like Zamdela (Sasolburg) became sites of major protests during the second half of 1984. These protests gradually filtered into other towns and the province began to witness a number of attacks, some fatal on councillors and their property. In return the councillors spearheaded attacks on their opponents, sometimes drawing together an informal vigilante groups charged with the task of 'cleaning up' areas that were known for opposition to that their system of local government (TRC Report, 3: p361). A considerable number of black councillors resigned in 1985, many of them evidently in response to fear of violent attack. Other reasons cited by councillors included family pressure, lack of protection by government, ill health, lack of progress and a realisation that the councils were ineffective.

The TRC heard that individual councillors were responsible for setting up some of these vigilante groups because they felt to be under constant attack from militant township youth. In some cases, councillors were actively involved in vigilante actions, supplying arms and participating personally in attacks on township residents and activists thought to be aligned to the UDF. Some vigilante groups were set up by members of the security forces, under the instruction of senior security police officers (Twala, 2012: p101-120; Twala, 2013: p289-301; Moloi, 2013: p1209-1216).

\subsubsection{Killings by the state organs}

As indicate before in this article, the students and the youth were at the forefront of the struggles since the late 1970s. With the call for a 'people's war' and the development of 'structures of people's power', the students created barricades, and destroyed the homes of school committee members. On the other hand, the students themselves suffered the consequences. They were maimed, tortured, detained and forced into hiding and exile. In July 1984 Thabong students engaged in a class boycott but his flared into two days of arson and stoning when police stepped in to stop the boycott. A crippled youth $\mathrm{P}$ Loape was shot dead by the police on the second day of open conflict. Consequently, sporadic violence and disruption of classes continued in Thabong throughout the rest of 1984 and 1985 and school examinations were not written at the end of these years (Haysom, 1986: p18-19).

As in other parts of the country, deaths in custody were often explained by the police force as 'suicide', or as occurring 'while escaping from police custody'. Official police statements following deaths in custody were often at variance with the evidence of witnesses and families of the deceased. The deaths of individuals who were last seen being arrested by police officers have often remained entirely unexplained. For example, $S$ Mutsi from Kutlwanong in Odendaalsrus was arrested on 4 May 1985. Two days thereafter he was reported to have died in police custody. It was evident that he was killed by the police. The above examples are some of the many incidents that took place in police custody (Mutsi, 2012). 


\subsubsection{How the families were traumatised}

As initially mentioned in this article, not only the political activists experienced trauma but also their families and immediate relatives. Their parents were constantly harassed by the police who would search their homes anytime of the day. Some parents witnessed as to how their parents were assaulted and this was evident by their state of health upon release from detention. Most of the political activists interviewed mentioned that their involvement in politics has had a life threatening effect upon their families and as a result the latter suffered trauma even though it was indirect.

\section{Conclusion}

The study argued that relationship between apartheid and the collective memory of its principal victim, the black population of South Africa, is complex. The apartheid system was distinct from prior political orders in South Africa's past in as much as it aimed at comprehensive and systematic racial separation and discrimination. The study placed emphasis on the traumatic experiences of the ANC political activists in the Free State, how they experienced their encounter with apartheid agents. Political activists experienced trauma in prisons and where they were held for detention. The study highlighted that in some cases political activists were tortured, killed and sometimes placed in solitary confinement. The constant fear of death in detention was a traumatic reality for many of the political activists. As mentioned above, the circumstances of their fellow activists who died in prison were to a certain extent hidden by the apartheid agents. For example, some political activists were assaulted physically and in most cases denied medical assistance. It was embarrassing to note that many of these political activists never received any therapy after being released from prisons.

\section{References}

Anon 2000. American Psychiatric Association. Diagnostic and Statistical Manual of Mental Disorders. Washington DC.

Brewin CR and Holmes EA 2003. 'Psychological theories of posttraumatic stress disorder'. In Clinical Psychology Review 23: 339-376.

Giller E s.a. 'What is psychological trauma', http://wwww.soberrecovery.com/forums/friends-family-alcoholics/214177-what-psychologicaltrauma.html>, accessed on 12 April 2013.

Haysom N 1986. Mabangalala: The rise of rightwing vigilantes in South Africa: Johannesburg.

Horowitz, MJ 1976. Stress Response Syndrome. New York: Aronson.

Koss MP 1993. 'Detecting the scope of rape: A review of prevalence research methods'. In Journal of Interpersonal Violence 8(2), June: 198-222.

Mbatha NPZ 2011. Historical Perspectives on women as victims of human rights violations and the Truth and Reconciliation Commission of South Africa (TRC), 1996-1998. Unpublished MA Mini-Dissertation. University of the Free State. Bloemfontein.

Moloi T 2012. Black Politics in Kroonstad: Political Mobilisation, Protests, Local Government, and Generational Struggles, 1976 to 1995. Unpublished PhD Thesis. University of the Witwatersrand. Johannesburg.

Moloi T 2013. 'Black Student Politics in South Africa, 1990-1996', in Ndlovu S (ed.), The Road to Democracy in South Africa, 6, (19901996), Part 2: 1209-1216. Pretoria: UNISA Press.

Oelofse MM 2007. Remembering the truth: An oral history perspective on the victim hearings of the Truth and Reconciliation Commission of South Africa, 1996-1998. Unpublished PhD Thesis. University of the Free State. Bloemfontein.

Personal Collection: Interview with PI Mutsi, mother to S Mutsi in Odendaalsrus, Odendaalsrus, 9 December 2011.

Personal Collection: Interview with C Mokobo, former student activist in Welkom, Bloemfontein, 29 January 2012.

Personal Collection: Interview with O Khoabane, former student activist in Welkom, Bloemfontein, 31 January 2012.

Personal Collection: Interview with N Choane, former student activist in Bloemfontein, Bloemfontein, 19 July 2012.

Solomons K 1989. 'The Dynamic of Posttraumatic Stress Disorder in South African Political Ex-Detainees'. In American Journal of Psychotherapy, XLIII(2), April.

Truth and Reconciliation Commission (TRC) of South Africa Report 1998. Vol. 3.

Twala C and Seekings J 2010. 'Activist networks and political protest in the Free State, 1983-1990', in Ndlovu S (ed.), The Road to Democracy in South Africa, 4, (1980-1990), Part 1: 765-814. Pretoria: UNISA Press.

Twala C 2012. 'The Three Million Gang in Maokeng Township (Kroonstad) and the reaction of the African National Congress's aligned structures'. In Yesterday and Today, 7, July: 101-120.

Twala C 2013. 'The ANC and the politics of the Free State, 1990-1994', in Ndlovu S (ed.), The Road to Democracy in South Africa, 6 , (1990-1996), Part 1: 289-301. Pretoria: UNISA Press. 